Vol. 6, No. 1, 2020

\author{
Bohdan Trembach ${ }^{1}$, Aleksandr Grin ${ }^{2}$, Illia Trembach ${ }^{3}$ \\ 1. Welding Technology Department, Donbas State Engineering Academy, \\ Ukraine, Kramatorsk, Academic Street, 72, \\ Private Joint Stock Company "Novokramatorsky Mashinostroitelny Zavod”, Ukraine, Kramatorsk, \\ Ordzhonikidze Street, 5, E-mail: btrembach89@gmail.com, ORCID: 0000-0002-2305-8411 \\ 2. Welding Technology Department, Donbas State Engineering Academy, Ukraine, Kramatorsk, \\ Academic Street 72, E-mail: mf@dgma.donetsk.ua, ORCID: 0000-0002-3432-8149 \\ 3. Private Joint Stock Company “Novokramatorsky Mashinostroitelny Zavod”, Ukraine, Kramatorsk, \\ Ordzhonikidze Street, 5, E-mail: i_trembach@ukr.net, ORCID: 0000-0002-3932-2520

\section{STUDY OF THE INFLUENCE OF THE ADDITION OF AN EXOTHERMIC MIXTURE AND THE RATIO OF THE COMPONENTS OF THE EXOTHERMIC MIXTURE ON THE MELTING INDICES AT FCAW}

Received: May 19, 2020 / Revised: July 29, 2020 / Accepted: July 31, 2020

(C) Trembach B., Grin A., Trembach I., 2020

\begin{abstract}
An important issue in the processes of strengthening and restoration of surfaces exposed to abrasive, abrasive-corrosive and hydroabrasive wear, using the process of self-protective flux-cored arc welding (FCAW), is to increase the productivity of hardfacing and the quality of the hardfacing metal. The literature review showed that one of the ways to increase the productivity of hardfacing and improve the quality of the hardfaced metal is to add an exothermic mixture to the core filler of flux-cored wire electrode. The effect of composition of filler core during FCAW on the fusion parameters, namely the addition of exothermic mixture (TM), the ratio of exothermic mixture components $(\mathrm{CuO} / \mathrm{Al})$, and the ratio of exothermic mixture oxidant to carbon content in the core composition $(\mathrm{CuO} / \mathrm{C})$ has been studied. It has been found that the optimum areas for the deposition rate $\left(\mathrm{G}_{\mathrm{d}}\right)$, deposition factor $(\mathrm{ad})$ and spattering factor $\left(\psi_{\mathrm{s}}\right)$ are observed for the following values of the core components: $\mathrm{TM}=25 \ldots 39, \mathrm{CuO} / \mathrm{C}=5 \ldots 6, \mathrm{CuO} / \mathrm{Al}=3 \ldots 4$.
\end{abstract}

Keywords: hardfacing, FCAW-S, exothermic mixture, simplex-centroid design, deposition rate, deposition rate factor, spattering factor, composition.

\title{
Introduction
}

Mining and processing plants and mining companies in Ukraine and around the world annually spend thousands of tons of metal on the manufacture of spare parts to replace wear parts. Regarding the conditions and the intensity of the wear processes are integral part of the instruments lifetime and reliability as well as of the whole systems. Hardfacing of parts is used to increase service life, manufacturability, and reduce production costs [1]. Throughout the diversity of reinforcement and restoration processes, the use of flux-cored wires (FCAW) has become widespread. When hardfacing FCAW, as well as FCAW-S, obtaining the hardfacing metal of a given chemical composition, the required quality (in the content of non-metallic inclusions), as well as high technical and economic performance of the works (deposition rate and deposition rate factor) play an important role [2], [3], [4]. At the same time, the most important characteristics of deposition technologies are: deposition rate, deposition rate factor and the spattering factor [2]-[5].

\section{Problem Statement}

During the melting of flux-cored wires, due to the lag of the melting of the core from the metal wire sheath, a protrusion of the core is formed at the end of the flux-cored wire. This protrusion can be destroyed with the formation of large particles, which, when they enter the molten bath without having to 
melt, can cause exogenous inclusions [6]. In addition, the lag of the melting of the core from the metal wire sheath, which causes deterioration of the welding performance and reduces the effectiveness of protection of weld metal from the air [2], [7]. One way to ensure uniformity of melting of the FCAW is to introduce into the core filler of the exothermic mixture [4], [8], [9].

\section{Review of Modern Information Sources on the Subject of the Paper}

The most common exothermic systems are $\mathrm{Fe}_{2} \mathrm{O}_{3}-\mathrm{Al}, \mathrm{Fe}_{2} \mathrm{O}_{3}-\mathrm{Ti}$ [10], while the $\mathrm{CuO}-\mathrm{Al}$ system is of great interest [8], due to the greatest thermal effect, which makes it possible to exclude the possibility of the charge entering the weld bath when a smaller amount of exothermic is introduced, which makes it possible to achieve a higher degree of doping of weld metal. In addition, when using thermal mixtures of other systems, such as $\mathrm{CuO}$, due to the reduction of the oxidant, the latter enters the metal, thereby doping it, which provides an even higher level of doping [8].

It is known that alloys with high carbon content are used for hardfacing of abrasive and hydroabrasive wear parts [12]. It is known that the recovery of copper oxide in exothermic mixtures can occur both aluminium and carbon. In this case, the degree and completeness of recovery by a particular reducing agent will depend on the ratio of components in the FCAW-S charge at constant other parameters. In the modern literature there is no data on the study of the influence of the ratio of the components of the core filler, namely the components of the exothermic mixture $\mathrm{CuO}-\mathrm{Al}$ and carbon. Thus, it is of considerable interest to study the effect of components of the exothermic mixture on the melting indices of the FCAW-S, to determine the optimal ratio of oxidant to the reducing agents of aluminium and carbon, as well as the optimal amount of exothermic mixture.

The objective of the paper. Determination of the nature of the effect and optimal values of the amount of exothermic mixture (TM), and the ratio of $\mathrm{CuO} / \mathrm{Al}$ and $\mathrm{CuO} / \mathrm{C}$ in the composition of FCAW-S filler on the qualitative indicators of its fusion using simplex-lattice design.

\section{Materials and methods}

To investigate the effect of FCAW-S core composition on fusion rates, a standard three-factor simplex-centroid design has been selected. Experiments are being conducted to investigate the effect of filler components (amount of exothermic mixture) on the deposition rate $\left(\mathrm{G}_{\mathrm{d}}\right)$, deposition rate factor $\left(\mathrm{a}_{\mathrm{d}}\right)$ and spattering factor $\left(\psi_{\mathrm{s}}\right)$. The design in coded values is shown in Table 1. To transmit from the simplex coordinate system to the natural values of the factors the following formulae are used Eq.1-3:

$$
\begin{aligned}
& (\mathrm{CuO} / \mathrm{C})=3+3 \cdot x_{1} ; \\
& (\mathrm{CuO} / \mathrm{C})=3+3 \cdot x_{2} ; \\
& (\mathrm{TM})=25+40 \cdot x_{3} .
\end{aligned}
$$

The design represented in natural values is also given in Table 1.

Table 1

Three-factor simplex-centroid experiment design

\begin{tabular}{|c|c|c|c|c|c|c|}
\hline \multirow{2}{*}{ No. } & \multicolumn{3}{|c|}{ Code values } & \multicolumn{3}{c|}{ Actual values } \\
\cline { 2 - 7 } & $x_{1}$ & $x_{2}$ & $x_{3}$ & $\mathrm{CuO} / \mathrm{C}$ & $\mathrm{CuO} / \mathrm{Al}$ & $\mathrm{TM} \%$ \\
\hline 1 & 0 & 1 & 0 & 3.00 & 6.00 & 25 \\
\hline 2 & 0.333 & 0.333 & 0.334 & 4.00 & 4.00 & 35 \\
\hline 3 & 0.667 & 0.333 & 0 & 5.00 & 4.00 & 25 \\
\hline 4 & 0 & 0.667 & 0.333 & 3.00 & 5.00 & 35 \\
\hline 5 & 0.333 & 0 & 0.667 & 4.00 & 3.00 & 45 \\
\hline 6 & 0.5 & 0.25 & 0.25 & 4.50 & 3.75 & 32.5 \\
\hline 7 & 0.25 & 0.25 & 0.5 & 3.75 & 3.75 & 40 \\
\hline 8 & 0.25 & 0.5 & 0.25 & 3.75 & 4.50 & 32.5 \\
\hline 9 & 0.333 & 0.667 & 0 & 4.00 & 5.00 & 25 \\
\hline
\end{tabular}


According to the experiment design matrix experimental wires have been produced the cores of which comprised components which composition is given in Table 2.

FCAW-S with exothermic mixture with a diameter of $4 \mathrm{~mm}$ have been made for the research. As a slag-forming component, a slag material has been used: marble-fluorite-rutile. Deposition has been performed by single-pass rollers on $10 \times 100 \times 200 \mathrm{~mm} \mathrm{~S} 235$ J2G2 EN 10025-2 (St3ps) low-carbon steel plates using a welding machine with a power source of constant voltage. Wire Filling Ratio: 0.34-0.35.

The technological characteristics of the melting of cored wires $G_{d}, \alpha_{d}$ and $\psi_{s}$, were calculated according to the following equation are used Eq. 4-6:

$$
\begin{gathered}
G_{d}=\frac{m_{d} \cdot 3600}{t} ; \\
\alpha_{d}=\frac{G_{d}}{I_{a s w}} ; \\
\psi_{s}=\frac{m_{m}-m_{s}}{m_{m}} \cdot 100 \%,
\end{gathered}
$$

where $m_{m}$ - the mass of molten electrode metal, g; $m_{d}$ - the mass of deposited metal, $\mathrm{g} ; m_{s}$ - the mass of spattering, $\mathrm{g} ; t$ - surfacing time, sec; $I_{a s w}$ - welding current, Amp.

\begin{tabular}{|c|c|c|c|c|c|c|c|c|c|c|}
\hline \multicolumn{2}{|c|}{ The name of the component } & 1 & 2 & 3 & 4 & 5 & 6 & 7 & 8 & 9 \\
\hline \multirow{3}{*}{$\begin{array}{l}\text { Gas slag } \\
\text { creating }\end{array}$} & Fluorspar GOST 4421-73 & \multirow{3}{*}{24} & \multirow{3}{*}{21} & \multirow{3}{*}{24} & \multirow{3}{*}{21} & \multirow{3}{*}{21} & \multirow{3}{*}{24} & \multirow{3}{*}{21} & \multirow{3}{*}{24} & \multirow{3}{*}{24} \\
\hline & $\begin{array}{l}\text { Rutilovy concentrate } \\
\text { GOST 22938-78 }\end{array}$ & & & & & & & & & \\
\hline & $\begin{array}{l}\text { Calcium carbonate } \\
\text { GOST 8252-79 }\end{array}$ & & & & & & & & & \\
\hline \multirow{5}{*}{$\begin{array}{l}\text { Alluring } \\
\text { and } \\
\text { deoxidizers }\end{array}$} & $\begin{array}{l}\text { Titanium powder } \\
\text { PTM TU 14-22-57-92 }\end{array}$ & \multirow{5}{*}{41} & \multirow{5}{*}{41} & \multirow{5}{*}{41} & \multirow{5}{*}{41} & \multirow{5}{*}{34} & \multirow{5}{*}{41} & \multirow{5}{*}{38} & \multirow{5}{*}{41} & \multirow{5}{*}{41} \\
\hline & $\begin{array}{l}\text { Ferrosilicon FS-75 } \\
\text { GOST } 1415-78\end{array}$ & & & & & & & & & \\
\hline & $\begin{array}{l}\text { Ferromanganese FMN-88A } \\
\text { GOST 4755-91 }\end{array}$ & & & & & & & & & \\
\hline & $\begin{array}{l}\text { Metal Chrome X99 } \\
\text { GOST 5905-79 }\end{array}$ & & & & & & & & & \\
\hline & $\begin{array}{l}\text { Ferovanadiy FVd-50 } \\
\text { GOST 27130-94 }\end{array}$ & & & & & & & & & \\
\hline \multicolumn{2}{|c|}{ Graphite is silver } & 5.6 & 5.8 & 3.45 & 7.6 & 7.1 & 4.9 & 7 & 5.8 & 4.3 \\
\hline \multicolumn{2}{|c|}{ Oxide of copper powder-like GOST 1653979} & 16.7 & 25 & 17.25 & 22.8 & 28.5 & 21.8 & 26 & 21.8 & 17.3 \\
\hline \multicolumn{2}{|c|}{ Aluminium powder PA1 GOST 6058-73 } & 2.8 & 5.8 & 4.3 & 4.6 & 9.5 & 5.8 & 7 & 4.9 & 3.5 \\
\hline \multicolumn{2}{|c|}{ Iron powder PZhR-1 GOST 9849-86 } & 9.9 & 3.1 & 10 & 3 & 0 & 2.5 & 1 & 2.5 & 10 \\
\hline
\end{tabular}

Table 2

Composition of S-FCAW, \%

Results and Discussion

Results of the experiment and calculations $\left(\mathrm{G}_{\mathrm{d}}^{\mathrm{s}}, \alpha_{\mathrm{d}}^{\mathrm{s}}, \psi_{\mathrm{s}}^{\mathrm{s}}\right)$ are given in Table 3 .

The results of the analysis of the influence of factors on the deposition rate $\left(\mathrm{G}_{\mathrm{d}}\right)$, deposition rate factor $\left(\alpha_{\mathrm{d}}\right)$ and spattering factor $\left(\psi_{\mathrm{s}}\right)$ are given in Table 3 .

Analysis of the design data obtained using Statistica (StatSoft) system [11]. The results of the model significance obtained using Statistica program for three fusion indices are shown in Fig. 1. 


\section{Results of research}

\begin{tabular}{|c|c|c|c|c|c|c|c|}
\hline \multirow{2}{*}{ No. } & \multirow{2}{*}{$\begin{array}{c}\text { Welding } \\
\text { current } \\
\mathrm{I}_{\mathrm{awc}} \text {, } \\
\text { Amp }\end{array}$} & \multicolumn{2}{|c|}{ Deposition rate, $\mathrm{g} / \mathrm{h}$} & \multicolumn{2}{|c|}{$\begin{array}{c}\text { Deposition rate factor, } \\
\mathrm{g} / \mathrm{Amp} \cdot \mathrm{h}\end{array}$} & \multicolumn{2}{|c|}{ Spattering factor, $\%$} \\
\hline & & $\begin{array}{c}\text { Experimental, } \\
\mathrm{G}_{\mathrm{d}}{ }^{\mathrm{e}}\end{array}$ & $\begin{array}{c}\text { Calculated, } \\
\mathrm{G}_{\mathrm{d}}{ }^{\mathrm{s}}\end{array}$ & $\begin{array}{c}\text { Experimental, } \\
\alpha_{d}{ }^{\mathrm{e}}\end{array}$ & $\begin{array}{c}\text { Calculated, } \\
\alpha_{d}{ }^{s}\end{array}$ & $\begin{array}{c}\text { Experimental, } \\
\psi_{\mathrm{s}}{ }^{\mathrm{e}}\end{array}$ & $\begin{array}{c}\text { Calculated, } \\
\psi_{\mathrm{s}}^{\mathrm{e}}\end{array}$ \\
\hline 1 & 353.48 & 4.192 & 4.182 & 11.860 & 11.636 & 14.35 & 14.35 \\
\hline 2 & 356.9 & 4.686 & 4.765 & 13.130 & 12.210 & 9.90 & 9.90 \\
\hline 3 & 357.3 & 4.655 & 4.631 & 13.027 & 12.938 & 14.95 & 14.95 \\
\hline 4 & 372.22 & 4.590 & 4.604 & 12.331 & 12.643 & 13.62 & 13.62 \\
\hline 5 & 370.8 & 3.972 & 3.989 & 10.711 & 11.022 & 20.84 & 20.84 \\
\hline 6 & 380.58 & 4.806 & 4.847 & 12.628 & 12.875 & 9.74 & 9.74 \\
\hline 7 & 407.47 & 4.769 & 4.564 & 11.704 & 11.751 & 10.75 & 10.75 \\
\hline 8 & 395.85 & 4.654 & 4.706 & 11.756 & 12.000 & 10.85 & 10.85 \\
\hline 9 & 395.7 & 4.228 & 4.214 & 10.685 & 10.958 & 20.27 & 20.27 \\
\hline 10 & 372.6 & 3.844 & 3.893 & 10.317 & 10.116 & 17.94 & 17.38 \\
\hline
\end{tabular}

\begin{tabular}{||l|c|r|c|c|c|}
\multirow{4}{*}{ Source } & \multicolumn{6}{|l}{ Overall Fit of Model; Var.: GH, kg/h (CuO-C-Al-\%TM) } \\
& 3 Factor mixture design; Mixture total=1,, 10 Runs \\
\cline { 2 - 6 } & \multicolumn{1}{c|}{ SS } & df & MS & F & p \\
\hline Model & 1,023849 & 6 & 0,170641 & 8,966086 & 0,049807 \\
\hline Total Error & 0,057096 & 3 & 0,019032 & & \\
\hline \hline Total Adjusted & 1,080944 & 9 & 0,120105 & & \\
\hline
\end{tabular}

$\mathrm{a}$

\begin{tabular}{l|c|r|c|c|c}
\hline \multirow{2}{*}{ Source } & \multicolumn{6}{|l}{$\begin{array}{l}\text { Overall Fit of Model; Var.: } \mathbf{\alpha H}, \mathrm{g} / \text { Ah (CuO-C-Al-\%TM) } \\
\text { 3 Factor mixture design; Mixture total=1,, 10 Runs }\end{array}$} \\
\cline { 2 - 6 } & SS & df & MS & F & p \\
\hline Model & 8,448603 & 6 & 1,408100 & 4,166067 & 0,134486 \\
\hline Total Error & 1,013978 & 3 & 0,337993 & & \\
\hline \hline Total Adjusted & 9,462581 & 9 & 1,051398 & & \\
\hline
\end{tabular}

b

\begin{tabular}{|c|c|c|c|c|c|}
\hline \multirow[b]{2}{*}{ Source } & \multicolumn{5}{|c|}{$\begin{array}{l}\text { Overall Fit of Model; Var:: } \psi \mathrm{p}, \% \text { (CuO-C-Al-\%TM - Показа } \\
3 \text { Factor mixture design; Mixture total=1, 10 Runs }\end{array}$} \\
\hline & SS & df & MS & $\mathrm{F}$ & $p$ \\
\hline Model & 144,6512 & 6 & 24,10853 & 16,44746 & 0,021394 \\
\hline Total Error & 4,3974 & 3 & 1,46579 & & \\
\hline Total Adjusted & 149,0486 & 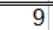 & 16,56095 & & \\
\hline
\end{tabular}

C

Fig. 1. Results of calculating the significance of the model by the residual sum of the squares: a - deposition rate $\left(\mathrm{G}_{\mathrm{d}}\right)$; b) deposition rate factor $\left(\alpha_{\mathrm{d}}\right)$; c) spattering factor $\left(\psi_{\mathrm{s}}\right)$

Statistically significant effects are observed when $p<0.05$ is a Student's test. Analyzing the data obtained, we can conclude that the models obtained are significant.

$$
\begin{gathered}
G_{d}=5.89299 \cdot x_{1}+4.20769 \cdot x_{2}+3.17881 \cdot \mathrm{x}_{3}-3.06163 \cdot x_{1} \cdot x_{2}-0.34053 \cdot x_{1} \cdot \mathrm{x}_{3}+ \\
+ \\
2.97135 \cdot x_{2} \cdot \mathrm{x}_{3}+10.67538 \cdot x_{1} \cdot x_{2} \cdot \mathrm{x}_{3} ; \\
\alpha_{d}=19.4971 \cdot x_{1}+11.91117 \cdot x_{2}+9.1192 \cdot \mathrm{x}_{3}-17.9461 \cdot x_{1} \cdot x_{2}+8.5066 \cdot x_{1} \cdot \mathrm{x}_{3}+ \\
+5.1104 \cdot x_{2} \cdot \mathrm{x}_{3}+36.6739 \cdot x_{1} \cdot x_{2} \cdot \mathrm{x}_{3} ; \\
\psi_{s}=0.2097 \cdot x_{1}+14.487 \cdot x_{2}+22 \cdot \mathrm{x}_{3}-46.4368 \cdot x_{1} \cdot x_{2}+28.036 \cdot x_{1} \cdot \mathrm{x}_{3}-16.2571 \cdot x_{2} \cdot \mathrm{x}_{3}- \\
-237.7167 \cdot x_{1} \cdot x_{2} \cdot \mathrm{x}_{3} .
\end{gathered}
$$

When turning the simplex coordinate system to the natural values of the factors we get the following equation:

$$
\begin{gathered}
G_{d}=-15.105+3.888 \cdot(\mathrm{CuO} / \mathrm{C})+2.1714 \cdot(\mathrm{CuO} / \mathrm{Al})+0.1508 \cdot(\mathrm{TM})-0.7922 \cdot(\mathrm{CuO} / \mathrm{C}) \cdot(\mathrm{CuO} / \mathrm{Al})- \\
-0.0601 \cdot(\mathrm{CuO} / \mathrm{C}) \cdot(\mathrm{TM})-0.029 \cdot(\mathrm{CuO} / \mathrm{Al}) \cdot(\mathrm{TM})+0.024 \cdot(\mathrm{CuO} / \mathrm{C}) \cdot(\mathrm{CuO} / \mathrm{Al}) \cdot(\mathrm{TM}) \\
\alpha_{d}=19.4971 \cdot x_{1}+11.91117 \cdot x_{2}+9.1192 \cdot \mathrm{x}_{3}-17.9461 \cdot x_{1} \cdot x_{2}+8.5066 \cdot x_{1} \cdot \mathrm{x}_{3}+ \\
+5.1104 \cdot x_{2} \cdot \mathrm{x}_{3}+36.6739 \cdot x_{1} \cdot x_{2} \cdot \mathrm{x}_{3} ; \\
\psi_{s}=0.2097 \cdot x_{1}+14.487 \cdot x_{2}+22 \cdot \mathrm{x}_{3}-46.4368 \cdot x_{1} \cdot x_{2}+28.036 \cdot x_{1} \cdot \mathrm{x}_{3}-16.2571 \cdot x_{2} \cdot \mathrm{x}_{3}- \\
-237.7167 \cdot x_{1} \cdot x_{2} \cdot \mathrm{x}_{3} .
\end{gathered}
$$

The resulting response surface simulations and contour plots are shown in Fig. 2. 

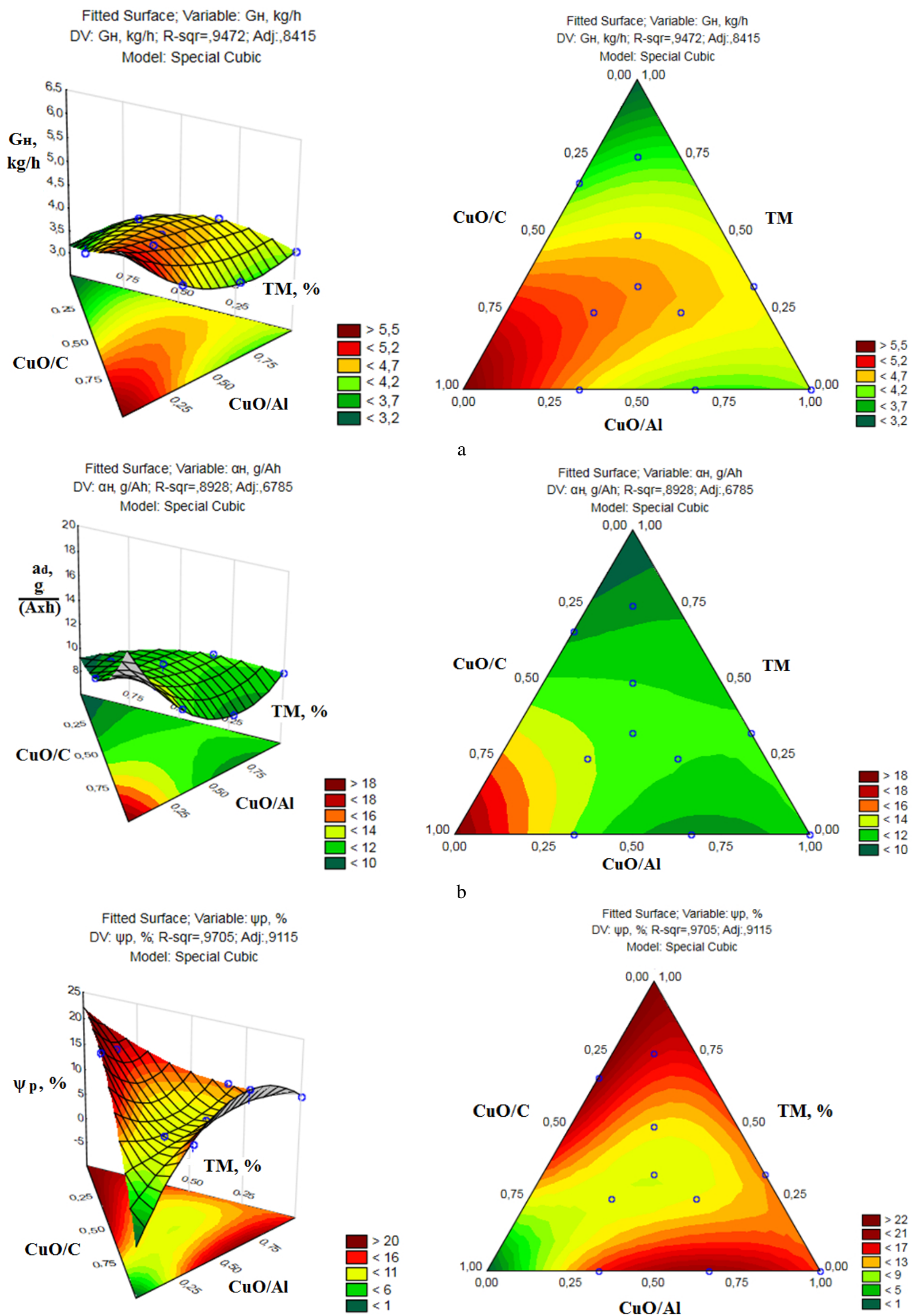

b

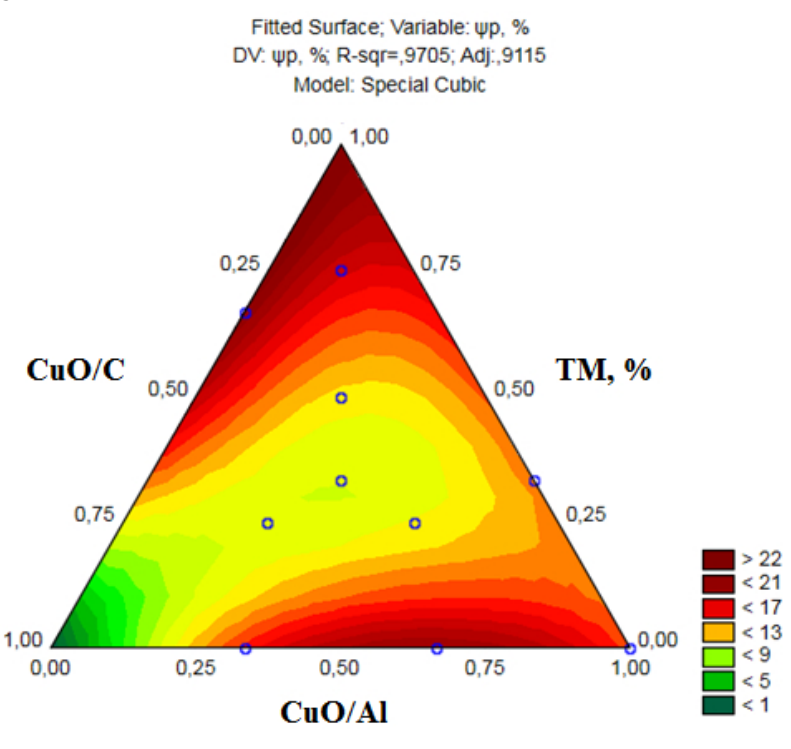

$\mathrm{c}$

Fig. 2. Response surface and color contour plot depending on exothermic mixture (TM) content, ratios $(\mathrm{CuO} / \mathrm{C})$ and $(\mathrm{CuO} / \mathrm{Al})$ for melting ratios: $\mathrm{a}-$ deposition rate $\left(\mathrm{G}_{\mathrm{d}}\right)$; b - deposition rate factor $\left(\alpha_{\mathrm{d}}\right)$; c - spattering factor $\left(\psi_{\mathrm{s}}\right)$. 


\section{Bohdan Trembach, Aleksandr Grin, Illia Trembach}

The highest values of deposition rate according to the results of the study depending on the response surfaces and contour plot (see Fig. 2,a) of the mathematical model (Eq. 10) correspond to the minimum amount of exothermic mixture (0...0.30, respectively) of the total fraction of the FCAW-S core, high ratios of $\mathrm{CuO} / \mathrm{C}=5 \ldots 6$ (code values $0.6 \ldots 1$ ), and low ratio $\mathrm{CuO} / \mathrm{Al}=3 \ldots 4$ (code values $0 \ldots 0.25)$. That is, in order to achieve high deposition rates in the composition of the flux wire, the amount of aluminum over the percentage of silver (carbon) graphite must prevail.

For deposition rate factor $\left(\alpha_{d}\right)$, the obtained dependencies are retained. According to the response surfaces and the contour plot obtained (Fig. 2, b), as well as the model obtained in natural equation (Eq. 11), the following values of the variable parameters correspond to the highest values of the deposition rate factor $\left(\alpha_{\mathrm{d}}\right): \mathrm{TM}=25 \ldots .39$ (code values $\left.0 \ldots 0.34\right) ; \mathrm{CuO} / \mathrm{C}=5 \ldots 6($ code values $0.6 \ldots 1) ; \mathrm{CuO} / \mathrm{Al}=3 \ldots 4$ (code values $0 \ldots 0.33$ ).

The analysis of the response surfaces obtained (Fig. 2, c) shows that the spattering loss factor $\left(\psi_{\mathrm{s}}\right)$ decreases with increasing of $\mathrm{Cu} / \mathrm{C}$ ratio, i.e. decrease in carbon (silver graphite) in the FCAW-S core composition, and decrease in $\mathrm{CuO} / \mathrm{Al}$ ratio. Technologically acceptable indicators are achieved at the following values: $\mathrm{TM}=25 \ldots 45$ (code values $0 \ldots 0.5$ ); $\mathrm{CuO} / \mathrm{C}=4.5 \ldots 6 \quad$ (code values $0.5 \ldots 1$ ); $\mathrm{CuO} / \mathrm{Al}=3 \ldots 4.5($ code values $0 \ldots 0.5)$.

The interpretation diagram of the imposition of certain areas of optimal values (Fig. 3) provides an opportunity to determine the optimal limit of the complex effect of the factors under the study.

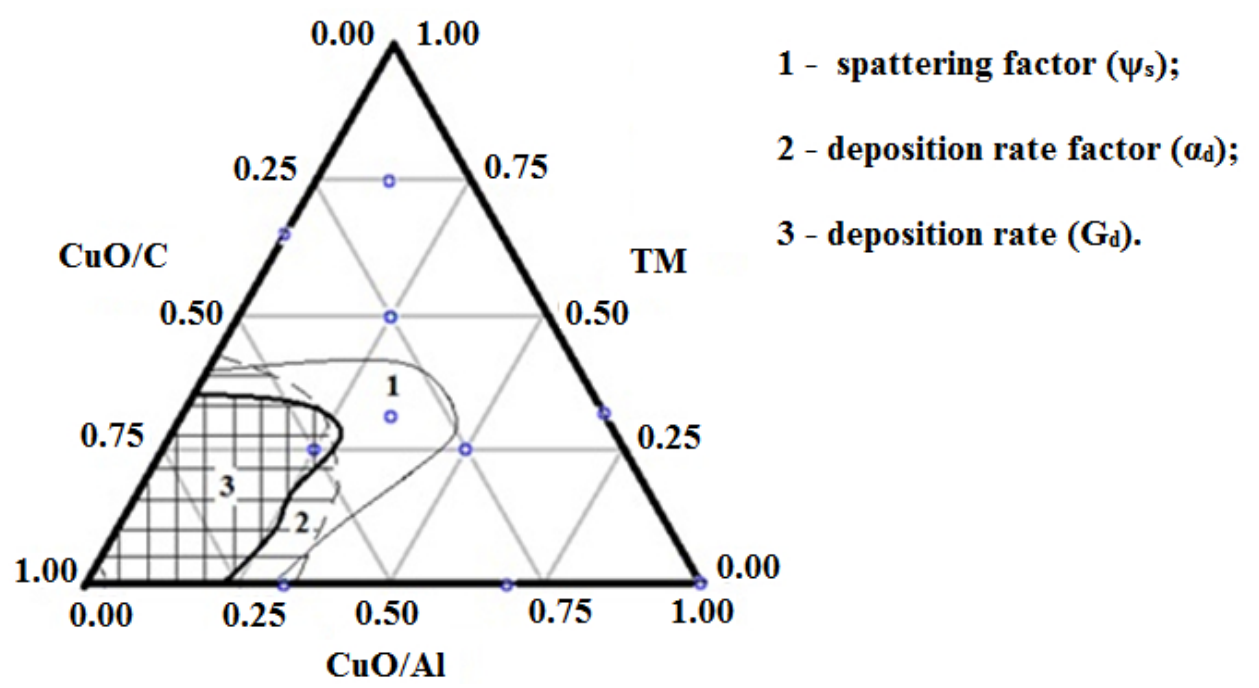

Fig. 3. Interpretation diagram of optimal value areas

It has been found that the optimum areas for the deposition rate $\left(G_{d}\right)$, deposition rate factor $\left(a_{d}\right)$ and spattering factor $\left(\psi_{\mathrm{s}}\right)$ are observed for the following values of the composition the core fillet of components: $\mathrm{TM}=25 \ldots 39, \mathrm{CuO} / \mathrm{C}=5 \ldots 6, \mathrm{CuO} / \mathrm{Al}=3 \ldots 4$.

\section{Conclusion}

As a result of the studies performed, the nature of the effect of the exothermic mixture and the ratios of the exothermic mixture $(\mathrm{CuO})$ oxidant to the exothermic mixture reducing agent $(\mathrm{Al})$, i.e. $\mathrm{CuO} / \mathrm{Al}$, and the exothermic oxidizer $(\mathrm{CuO})$ oxidant to the oxidizing agent to carbon $(\mathrm{C})$ have been determined.

Mathematical models have been obtained and response surfaces for the deposition rate $\left(G_{d}\right)$ indices, deposition factor $\left(\alpha_{\mathrm{d}}\right)$, and spattering factor $\left(\psi_{\mathrm{s}}\right)$ depending on the content of the components of the exothermic mixture and the carbon core of the flux wire have been built.

The greatest effect on the welding and process characteristics of FCAW-S has the ratio of components of $\mathrm{CuO} / \mathrm{Al}$ exothermic mixture.

High values of deposition rate and the lowest values of the spattering factor are achieved with a larger amount of aluminum powder, ie with the ratio of oxidant to reducing agent greater than their stoichiometric value, i.e. $\mathrm{CuO} / \mathrm{Al}=3 \ldots 4$. 


\section{References}

[1] John J. Coronado, Holman F. Caicedo, and Adolfo L. Gómez., "The effects of welding processes on abrasive wear resistance for hardfacing deposits", Tribology International, vol. 42, no. 5, pp. 745-749, October, 2009.

[2] I. K. Pohodnja, A. M. Suptel', and V. N. Shlepakov, Svarka poroshkovoj provolokoj [Flux-cored wire arc welding]. Kiev, Ukraine: Naukova dumka Publ., 1972. [in Russian].

[3] S. V. Zharykov, A. H. Hryn, and L. V. Vasyleva, "Optymyzatsyia rezhymov naplavky samozashchytnoi poroshkovoi provolokoi s ekzotermycheskoi smesiu" ["Optimization of surfacing modes with self-shielded flux-cored wire with an exothermic mixture"]. Visnyk Donbaskoi derzhavnoi mashynobudivnoi akademii [Herald of the Donbass State Engineering Academy], vol. 38. no. 2, pp. 116-120, 2016. [in Russian].

[4] B. Trembach, A. Grin, S. Zharikov, and I. Trembach, "Investigation of powder wire with the $\mathrm{CuO} / \mathrm{Al}$ exothermic mixture", Visnyk Ternopil's'koho natsional'noho tekhnichnoho universytetu [Scientific journal of the Ternopil National Technical University], vol. 92. no. 4, pp. 13-23, January, 2018.

[5] A. A. Erohin, Osnovy svarki plavleniem [Fundamentals of fusion welding]. Moscow, Russia: Mashinostroenie Publ., 1973. [in Russian].

[6] Ju. A. Juzvenko, G. A. Kiriljuk, and S. Ju. Krivchikov, "Model plavlenija samozashhitnoj poroshkovoj provoloki" ["Self-shielded flux cored wire melting model"], Avtomaticheskaja svarka [Automatic Welding], vol. 1. pp. 26-29, 1983. [in Russian].

[7] Ju. A. Juzvenko, and G. A. Kiriljuk, Naplavka poroshkovoj provolokoj [Flux-cored wire surfacing]. Moscow, Russia: Mashinostroenie Publ., 1973. [in Russian].

[8] V. V. Chigarev, D. A. Zarechensky, and A. G. Belik, "Peculiarities of melting of flux-cored strips with exothermic mixtures contained in their filler", The Paton Welding Journal, no. 2, 46-48, 2007.

[9] Y. D. Park, N. Kang, S. H. Malene, and D. L. Olson, "Effect of exothermic additions on heat generation and arc process efficiency in flux-cored arc welding", Metals and Materials International, vol. 13, no. 6, pp. 501$509,2007$.

[10] O. M. Ioffe, O. M. Kuznecov, and V. M. Piteckij, "Vlijanie titano-termitnoj smesi, vhodjashhej v jelektrodnoe pokrytie, na povyshenie proizvoditel'nosti svarki" ["Effect of titanium-thermite mixture included in the electrode coating on increasing welding productivity"], Svarochnoe proizvodstvo, vol. 3, pp. 26-28, 1980. [in Russian]. 